\section{BMJ Open}

Ophthalmology

\title{
Short-chain cyanoacrylates and long- chain cyanoacrylates (Dermabond) have different antimicrobial effects
}

\author{
Richard Yudi Hida (1) , ${ }^{1,2,3}$ Cely Barreto Silva (D) , ${ }^{4}$ Ivana Lopes Romero-Kusabara, ${ }^{5}$ \\ Lycia Mara Jenne Mimica ${ }^{4}$
}

To cite: Hida RY, Silva CB, Romero-Kusabara IL, et al. Short-chain cyanoacrylates and long-chain cyanoacrylates (Dermabond) have different antimicrobial effects. BMJ Open Ophthalmology 2021;6:e000591. doi:10.1136/ bmjophth-2020-000591

Received 16 August 2020 Revised 19 December 2020 Accepted 31 December 2020

Check for updates

(C) Author(s) (or their employer(s)) 2021. Re-use permitted under CC BY-NC. No commercial re-use. See rights and permissions. Published by BMJ.

${ }^{1}$ Department of Ophthalmology, Universidade Federal de São Paulo (UNIFESP), São Paulo, Brazil

${ }^{2}$ Department of Ophthalmology, Keio University- School of Medicine, Tokyo, Japan ${ }^{3}$ Department of Ophthalmology, Universidade de São Paulo (USP), São Paulo, Brazil ${ }^{4}$ Department of Microbiologia, Faculdade de Ciências Médicas da Santa Casa de São Paulo, Sao Paulo, São Paulo, Brazil ${ }^{5}$ Department of Ophthalmology, Santa Casa de São Paulo, São Paulo, Brazil

Correspondence to Dr Richard Yudi Hida; ryhida@ gmail.com

\section{ABSTRACT}

Objective To compare the antimicrobial effect in vitro of a short-chain cyanoacrylate with a long-chain cyanoacrylate (Dermabond, Ethicon, Johnson and Johnson, USA) against bacterial strains.

Methods and analysis The following bacterial strains were analysed: Staphylococcus aureus, Escherichia coli, Klebsiella pneumonia and Pseudomonas aeruginosa. For each microorganism, standardised sterile discs $(6 \mathrm{~mm})$ containing $10 \mu \mathrm{L}$ of ethyl-cyanoacrylate and 2-octyl cyanoacrylate were applied to the plate. All plates received a blank filter-paper disc with no adhesive (control). All plates were incubated for 24 hours, after which the bacterial inhibitory halos, if present, were measured in millimetres in its greater length.

Results Inhibitory halos were observed for both adhesives for $S$. aureus. Inhibition halos were observed only for ethyl-cyanoacrylate for K. pneumoniae and $E$. coli. No inhibition halo was observed for $P$. aeruginosa in any sample. The relationship between the total size of the inhibition halos and the diameter of the paper filter for $S$. aureus was statistically significant compared with 2-octyl cyanoacrylate.

Conclusion Data shown conclude that ethylcyanoacrylate showed in vitro bacteriostatic activity for $S$. aureus, E. coli and K. pneumoniae. 2-0ctyl cyanoacrylate showed in vitro lower bacteriostatic activity only against $S$. aureus when compared with ethyl-cyanoacrylate. No in vitro bactericidal activity of ethyl-cyanoacrylate or 2-octyl cyanoacrylate was observed.

\section{INTRODUCTION}

Cyanoacrylate is a well-known organic adhesive polymer used in the medical area. $^{1-7}$ The cyanoacrylate monomer is synthesised by the condensation of formaldehyde and cyanoacetate molecules resulting in a polymer called polycyanoacrylate. Since this reaction is reversible, it will be degraded, once again forming formaldehyde monomers and cyanoacetate. It is believed that this degradation mechanism is probably responsible for the toxic effect in human tissues. The greater the amount of adhesive used, the greater

\section{Key messages}

What is already known about this subject?

- First generation cyanoacrylate used to seal corneal injuries has already known for higher antimicrobial effect. Antimicrobial effect of the new generation cyanoacrylate is still unknown against microorganism related to eye infections.

What are the new findings?

- New generation cyanoacrylate (Dermabond) has shown minimal antimicrobial effect when compared to first generation cyanoacrylate.

How might these results change the focus of research or clinical practice?

- Considering that studies have shown that old generation cyanoacrylate (short-chain) have higher toxicity (induces vascularisation) against human tissue, the results of our study, suggest the application of short-chain cyanoacrylate to be used in cases of infected corneal thinning/perforations located away from the limbus due to its higher antimicrobial activity and toxicity (induces vascularisation). New generation cyanoacrylate is preferred to be used in cases of sterile and/or infected corneal thinning or perforations located near the limbus due to its lower antimicrobial activity and lower toxicity (induces less vascularisation)

the inflammatory response. Short-chain compounds such as ethyl-cyanoacrylate (EC) are more toxic and have faster degradation. Long-chain compounds such as 2-octyl cyanoacrylate (OC) have low toxicity and slow degradation. ${ }^{8-12}$

Antimicrobial activity of n-butyl-2cyanoacrylate and EC was already studied against gram-positive and gram-negative microorganisms by several authors. ${ }^{13-16}$ Previous studies performed by our group have shown in vitro antibacterial benefits of cyanoacrylate that varies in a dose-dependent fashion with its volume. ${ }^{16}$ These studies can support the fact that cyanoacrylate can successfully help in the wound healing process in cases associated 
with infection. As for the OC, its antimicrobial benefits and mechanisms are still unknown. There are reports showing the importance of the degradation process on the antimicrobial effect of OC without analysing the effects of the polymerisation process. ${ }^{1718}$ The cyanoacrylate polymerisation process plays an important role on the antimicrobial effect of all cyanoacrylates. ${ }^{15}$ The antimicrobial effect of polymerisation with degradation process of OC has never been analysed together as a whole (search protocol source: Pubmed; keywords: octyl-cyanoacrylate, Dermabond, antimicrobial; year: all).

The purpose of this study is to compare the antimicrobial effect in vitro of a shortest chain cyanoacrylate (EC) with a long-chain cyanoacrylate (OC) (Dermabond, Ethicon, Johnson and Johnson, USA) against bacterial strains.

\section{MATERIAL AND METHOD}

The study was conducted at the Microbiology Laboratory of the Department of Microbiology of the Serviço de Controle de Infecção Hospitalar of the Medical School of Santa Casa de Misericórdia de São Paulo.

The following bacterial strains from the American Type Culture Collection (ATCC) were analysed: Staphylococcus aureus (ATCC25923), Escherichia coli (ATCC25922), Klebsiella pneumoniae (ATCC13883) and Pseudomonas aeruginosa (ATCC27853). They were primarily incubated in a nutrient broth (tryptic soy broth) at $35^{\circ} \mathrm{C}$ until reaching 0.5 on the McFarland turbidity scale (represents turbidity of bacterial suspension at approximate population of $1.5 \times 10^{8}$ microorganisms per cubic centimetre). ${ }^{19}$ The bacteria were then transferred as monolayer cultures to Müeller-Hinton media following modified KirbyBauer technique ${ }^{20}{ }^{21}$ according to standards of the National Committee for Clinical Laboratory Standards.

For each organism, 10 standardised sterile filterpaper blank discs measuring $6 \mathrm{~mm}$ in diameter containing $10 \mu \mathrm{L}$ of EC (Superbonder, Loctite, Brazil) were applied to the plate and 10 other discs with $10 \mu \mathrm{L}$ of OC (Dermabond, Ethicon, Johnson and Johnson, USA) were also applied to the plates. Both adhesives were applied directly onto the filter-paper disc using micropipette and disposable tips (Eppendorf, Hamburg, Germany). All plates received a blank filter-paper disc with no adhesive in the centre (control). All plates were incubated at $35^{\circ} \mathrm{C} \pm 2^{\circ} \mathrm{C}$ for 24 hours, after which the inhibitory halos, if present, were measured in millimetres in its greater length (figure 1). All standardised tests were duplicated.

OC is presented by the manufacturer in a glass ampoule, surrounded by a plastic ampoule with a sponge applicator, at one end of the vial, which contains a catalyst (benzalkonium chloride). For this study, the vial was carefully withdrawn and OC was manipulated with sterile micropipette.
For statistical analysis, the relationship between inhibition halo and the filter paper was calculated as the ratio of the diameter of the disc $(6 \mathrm{~mm})$ and the total size of the inhibition halo (at its greatest length) (figure 1).

In order to evaluate if the bacterial inhibitory halos were the result of actual bactericidal effects, samples from the clear area within the inhibitory halo were collected after 48 hours and re-cultured on new bacterial culture plates. The new plates were then re-incubated at $35^{\circ} \mathrm{C} \pm 2^{\circ} \mathrm{C}$ and analysed after 48 hours.

All measurements of inhibitory halos were performed by one individual and confirmed by another individual. The results the ratio were statistically analysed with Student's t-test and significance was defined as $\mathrm{p}<0.05$.

\section{RESULTS}

Table 1 shows the average and SD of the inhibition halo $(\mathrm{mm})$ representing the antimicrobial activity of EC, OC and control group for the microorganisms studied.

Data show the presence of antimicrobial activity for both adhesives against $S$. aureus. Data also show the presence of antimicrobial activity for EC against $K$. pneumoniae and E. coli.

No inhibition halo was observed for $P$. aeruginosa in any samples. No inhibition halo was observed in any control samples.

Table 2 shows the average and SD of the ratio of the disk diameter $(6 \mathrm{~mm})$ and the total size of the inhibition halo, when present, of EC, OC and control representing the quantification of antimicrobial activity of the adhesives against microorganisms studied.

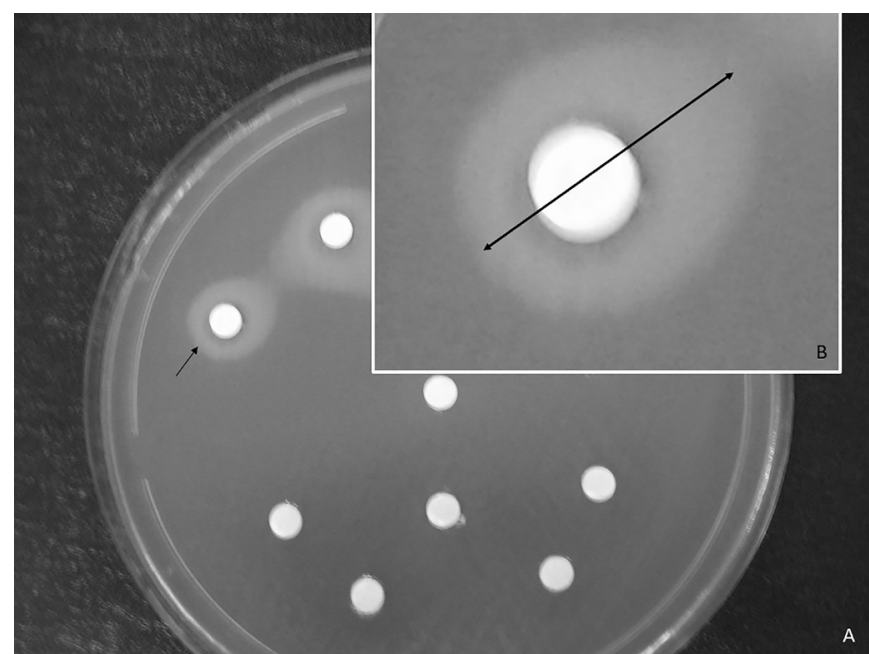

Figure 1 (A) Muller-Hinton media plate showing inhibitory halos around sterile filter paper with cyanoacrylate adhesive 24 hours after application showing white inhibitory halo around the filter paper (black arrow). (B) Measurement of total size of inhibitory halo at its greatest length (black arrow). 
Table 1 Average and SD of the inhibition halo and paper filter disc size $(6 \mathrm{~mm})$ in millimetres, showing the antimicrobial activity of ethyl-cyanoacrylate and 2-octyl cyanoacrylate for different microorganisms

\begin{tabular}{llcll}
\hline & EC & OC & C & P value \\
\hline Staphylococcus aureus & $18.1 \pm 2.55$ & $12.5 \pm 1.24$ & 6.00 & $<0.0001$ \\
Pseudomonas aeruginosa & 6.00 & 6.00 & 6.00 & NA \\
Klebsiella pneumoniae & $11.05 \pm 0.50$ & 6.00 & 6.00 & NA \\
Escherichia coli & $14.25 \pm 0.83$ & 6.00 & 6.00 & NA \\
\hline
\end{tabular}

C, control; EC, ethyl-cyanoacrylate; OC, 2-octyl-cyanoacrylate.

Our data show that EC has higher antimicrobial activity against $S$. aureus $(\mathrm{p}<0.0001)$ when compared with OC. EC also showed higher and important antimicrobial activity against $K$. pneumoniae $(\mathrm{p}<0.0001)$ and E. coli $(\mathrm{p}<0.0001)$ when compared with OC.

No microorganisms were observed on the re-cultured plates of samples collected from the clear area within the inhibitory halo, showing no bactericidal activity.

\section{DISCUSSION}

The present study shows that bacteriostatic activity of EC is statistically higher than OC for some microorganisms. This fact reinforces the hypothesis that adhesive toxicity may be directly proportional to its antimicrobial activity; however, different degradation rates of EC and OC may possibly be another factor to influence in the sizes of inhibition halo.

Previous studies, using EC directly to the bacterial strain, have reported bacteriostatic and bactericidal activity against some microorganisms. ${ }^{13}$ Our study has also showed bacteriostatic activity of EC against $S$. aureus and E. coli, supporting these reports. However, no bactericidal activity was observed in our study. ${ }^{1516}$ Direct contact of EC to the bacterial plates, in previous studies, might explain higher bactericidal activity then using discs. We also believe that the EC is not potent enough to cause any structural damage to destroy bacteria.

It is known that cyanoacrylates easily connect to free amine groups and hydroxyl, groups found in the cell wall of gram-positive microorganisms. This would explain the bacteriostatic activity exerted by the adhesive against such bacteria. Structural differences of the outer capsule of E. coli can explain its heterogeneous behaviour in relation to other gram-negative bacteria; however, other studies must be performed to clarify such fact. ${ }^{22} 23$

Our data observed that none of the adhesives studied showed antimicrobial activity against $P$. aeruginosa, confirming previous reports analysing EC. ${ }^{13} 1516$ Since long-chain compounds such as OC have shown in other studies, lower toxicity and slower degradation, it is expected that OC has the same or lower antimicrobial activity than EC. EC antimicrobial activity also supports previous data shown by our group. ${ }^{131516}$

Considering the results of our study, EC is preferred to be used in cases of infected corneal thinning or perforations located away from the limbus due to its higher antimicrobial activity and toxicity (can induce vascularisation). ${ }^{13} 15162425$ And $\mathrm{OC}$ is preferred to be used in cases of sterile and/or infected corneal thinning or perforations located near the limbus due to its lower antimicrobial activity and lower toxicity (induces less vascularisation). The cyanoacrylate's toxicity may be related to the cyanoacrylate's degradation products as the adhesive polymerisation process, which varies with the type of cyanoacrylate. ${ }^{15}$ The potential of all different cyanoacrylates against bacteria interacting with corneal epithelial cells in vitro may clarify the best indication for each human eye diseases.

Data shown in this study conclude that EC showed in vitro bacteriostatic activity for $S$. aureus (ATCC25923), E. coli (ATCC25922) and K. pneumoniae (ATCC13883). OC showed in vitro lower bacteriostatic activity only against S. aureus (ATCC25923) when compared with EC. No in vitro bactericidal activity of EC or OC was observed.

Table 2 Average and SD of the ratio of the diameter of the disc $(6 \mathrm{~mm})$ and the inhibition halo, when present, of EC, OC and control

\begin{tabular}{lllll}
\hline & EC & OC & C & P value \\
\hline Staphylococcus aureus & $3.02 \pm 0.43$ & $2.08 \pm 0.21$ & 1.00 & $<0.0001$ \\
Pseudomonas aeruginosa & 1.00 & 1.00 & 1.00 & NA \\
Klebsiella pneumoniae & $1.84 \pm 0.08$ & 1.00 & 1.00 & $<0.0001$ \\
Escherichia coli & $2.38 \pm 0.14$ & 1.00 & 1.00 & NA \\
\hline
\end{tabular}

C, control; EC, ethyl-cyanoacrylate; OC, 2-octyl-cyanoacrylate. 
Funding The authors have not declared a specific grant for this research from any funding agency in the public, commercial or not-for-profit sectors.

Competing interests None declared.

Patient and public involvement Patients and/or the public were not involved in the design, or conduct, or reporting, or dissemination plans of this research.

Patient consent for publication Not required.

Provenance and peer review Not commissioned; externally peer reviewed.

Data availability statement All data relevant to the study are included in the article.

Open access This is an open access article distributed in accordance with the Creative Commons Attribution Non Commercial (CC BY-NC 4.0) license, which permits others to distribute, remix, adapt, build upon this work non-commercially, and license their derivative works on different terms, provided the original work is properly cited, appropriate credit is given, any changes made indicated, and the use is non-commercial. See: http://creativecommons.org/licenses/by-nc/4.0/.

ORCID iDs

Richard Yudi Hida http://orcid.org/0000-0002-9745-8864

Cely Barreto Silva http://orcid.org/0000-0001-5404-3493

\section{REFERENCES}

1 Aksoy M, Turnadere E, Ayalp K, et al. Cyanoacrylate for wound closure in prosthetic vascular graft surgery to prevent infections through contamination. Surg Today 2006;36:52-6.

2 Barillari P, Basso L, Larcinese A, et al. Cyanoacrylate glue in the treatment of ano-rectal fistulas. Int J Colorectal Dis 2006;21:791-4.

3 Fotiadis C, Leventis I, Adamis S, et al. The use of isobutylcyanoacrylate as a tissue adhesive in abdominal surgery. Acta Chir Belg 2005;105:392-6.

4 Handschel JGK, Depprich RA, Dirksen D, et al. A prospective comparison of octyl-2-cyanoacrylate and suture in standardized facial wounds. Int J Oral Maxillofac Surg 2006;35:318-23.

5 Hile LM, Linklater DR. Use of 2-octyl cyanoacrylate for the repair of a fractured molar tooth. Ann Emerg Med 2006;47:424-6.

6 Landegren T, Risling M, Brage A, et al. Long-Term results of peripheral nerve repair: a comparison of nerve anastomosis with ethyl-cyanoacrylate and epineural sutures. Scand J Plast Reconstr Surg Hand Surg 2006;40:65-72.

7 Suter B. A new method for retrieving silver points and separated instruments from root canals. J Endod 1998;24:446-8.

8 de Azevedo CL, Marques MM, Bombana AC. Cytotoxic effects of cyanoacrylates used as retrograde filling materials: an in vitro analysis. Pesqui Odontol Bras 2003;17:113-8.
9 Evans CE, Lees GC, Trail IA. Cytotoxicity of cyanoacrylate adhesives to cultured tendon cells. J Hand Surg Br 1999:24:658-61.

10 Kaplan M, Baysal K. In vitro toxicity test of ethyl 2-cyanoacrylate, a tissue adhesive used in cardiovascular surgery, by fibroblast cell culture method. Heart Surg Forum 2005;8:E169-72.

11 Leggat PA, Kedjarune U, Smith DR. Toxicity of cyanoacrylate adhesives and their occupational impacts for dental staff. Ind Health 2004;42:207-11.

12 Thumwanit V, Kedjarune U. Cytotoxicity of polymerized commercial cyanoacrylate adhesive on cultured human oral fibroblasts. Aust Dent J 1999;44:248-52.

13 de Almeida Manzano RP, Naufal SC, Hida RY, et al. Antibacterial analysis in vitro of ethyl-cyanoacrylate against ocular pathogens. Cornea 2006;25:350-1.

14 Howell JM, Bresnahan KA, Stair TO, et al. Comparison of effects of suture and cyanoacrylate tissue adhesive on bacterial counts in contaminated lacerations. Antimicrob Agents Chemother 1995;39:559-60.

15 Romero IL, Malta JBNS, Silva CB, et al. Antibacterial properties of cyanoacrylate tissue adhesive: does the polymerization reaction play a role? Indian J Ophthalmol 2009;57:341-4.

16 Romero IL, Paiato TP, Silva CB, et al. Different application volumes of ethyl-cyanoacrylate tissue adhesive can change its antibacterial effects against ocular pathogens in vitro. Curr Eye Res 2008;33:813-8.

17 Prince D, Solanki Z, Varughese R, et al. Antibacterial effect and proposed mechanism of action of a topical surgical adhesive. Am J Infect Control 2018;46:26-9.

18 Rushbrook JL, White G, Kidger L, et al. The antibacterial effect of 2 -octyl cyanoacrylate (Dermabond $囚$ ) skin adhesive. J Infect Prev 2014;15:236-9.

19 Lennette EH, Ballows A, HauslerWJ. Manual of clinical microbiology. 4th edn. Washington D.C.: American Society for Microbiology, 1985.

20 Boyle VJ, Fancher ME, Ross RW. Rapid, modified Kirby-Bauer susceptibility test with single, high-concentration antimicrobial disks. Antimicrob Agents Chemother 1973;3:418-24.

21 Bauer AW, Kirby WM, Sherris JC, et al. Antibiotic susceptibility testing by a standardized single disk method. Am J Clin Pathol 1966;45:493-6.

22 Delcour AH. Function and modulation of bacterial porins: insights from electrophysiology. FEMS Microbiol Lett 1997;151:115-23.

23 Koebnik R, Locher KP, Van Gelder P. Structure and function of bacterial outer membrane proteins: barrels in a nutshell. Mol Microbiol 2000;37:239-53.

24 Bloomfield S, Barnert AH, Kanter P. The use of Eastman-910 monomer as an adhesive in ocular surgery. II. effectiveness in closure of limbal wounds in rabbits. Am J Ophthalmol 1963:55:946-53.

25 Bloomfield S, Barnert AH, Kanter PD. The use of Eastman 910 monomer as an adhesive in ocular surgery. I. biologic effects on ocular tissues. Am J Ophthalmol 1963;55:742-8. 